\title{
EVALUATING THE COMPETITIVE ENVIRONMENT FOR WILD PISTACHIO (Pistacia atlantica DESF.) SEEDLINGS IN THE CENTRAL FORESTS OF IRAN ${ }^{1}$
}

\author{
Bahman Kiani ${ }^{2 *}$ and Asma Amiri ${ }^{2}$
}

\footnotetext{
${ }^{1}$ Received on 08.08.2018 accepted for publication on 19.11.2018.

${ }^{2}$ Yazd University, Department of Forest Sciences, Ira. E-mail: <bnkiani@yazd.ac.ir> and <asmaj1368@yahoo.com>.

*Corresponding author.
}

\begin{abstract}
Wild pistachio (Pistacia atlantica Desf.) is an important tree species from dry forests of Eurasia. Seedlings must usually compete with other tree and shrub species in the dry harsh environment of mountain forests. In this study, we identified the main competitor species and evaluated some widely used competition indices, including distance-dependent and distance-independent ones, to quantify the relationship between the reference seedlings and their neighbors. The results indicated that the main competitors are mountain almond (Amygdalus scoparia Spach.), thorny almond (Amygdalus lycioides Spach.), montpellier maple (Acer monspessulanum subsp. cinerascens Boiss.) and other wild pistachio seedlings. We found that competition increases the height growth but reduces the diameter, basal area growth and crown development of wild pistachio seedlings. Some competition indices had a noticeable correlation with seedling growth, indicating that competition does exist. A combination of log-transformed indices could explain $85 \%$ of the diameter growth variations, $46 \%$ of height growth, $76 \%$ of basal area growth and $72 \%$ of crown area development with a good precision.
\end{abstract}

Keywords: Competition; Growth; Modeling.

\section{AVALIAÇÃO DO AMBIENTE COMPETITIVO DE MUDAS DE PISTACHE SELVAGEM (Pistacia atlantica DESF.) EM FLORESTAS CENTRAIS DO IRA}

\begin{abstract}
RESUMO - Pistache selvagem (Pistacia atlantica Desf.) é uma espécie arbórea importante nas florestas secas da Eurásia. As mudas geralmente devem competir com outras espécies de árvores e arbustos no ambiente severo e seco das florestas montanhosas. Neste estudo, identificou-se as principais espécies competidoras e se avaliou alguns índices de competição amplamente utilizados, incluindo os dependentes e os independentes da distância, para quantificar a relação entre as mudas de referência e suas vizinhas. Os resultados indicaram que as principais concorrentes são amêndoa de montanha (Amygdalus scoparia Spach.), amêndoa espinhosa (Amygdalus lycioides Spach.), bordo de montpellier (Acer monspessulanum subsp. cinerascens Boiss.) e outras mudas de pistache selvagem. Foi determinado que a competição promove o crescimento em altura e reduz o diâmetro, o crescimento da área basal e o desenvolvimento da copa das mudas de pistache silvestre. Alguns índices de competição tiveram uma correlação notável com o crescimento das mudas, indicando a existência de competição. Um composto de índices log-transformados explicou $85 \%$ das variações de crescimento no diâmetro, $46 \%$ na altura, $76 \%$ na área basal e $72 \%$ no desenvolvimento da área da copa, com uma boa precisão.
\end{abstract}

Palavras-Chave: Competição; Crescimento; Modelagem. 


\section{INTRODUCTION}

There is just a little research in literature focusing on competition effects on forest trees in Iran. One can refer to Hosseini et al. (2013) and Amiri and Naghdi (2016) as the only studies ever done. In spite of this research scarcity, quantifying the effects of competition on forest trees and seedlings is very important for managers. There is, indeed, more interest in evaluating the competitive environment for rare-regenerating species. Studies have shown that tree growth models can evaluate how growth varies with different levels of competition (Rivas et al., 2005). The present research focuses on evaluation of competition indices for predicting the growth of wild pistachio (Pistacia atlantica Desf.) seedlings in mountain forests.

Pistacia atlantica is a species of pistachio trees called 'Baneh' in Iran. This species originated in the Iranian plateau from where it migrated to North Africa and Palestine. Because of over-exploitation of its wood in Iran, it is now localized only on mountains (Pourreza et al., 2008). In some countries, the seeds are used for tanning and soap-making. Turpentine is the most important product of this tree, and it is, in fact, a resin. It has many therapeutic values and has been exported to other countries for many years. The leaves of wild pistachio often have galls (Quattrocchi, 2012), which contain noticeable amounts of tannins used to tan skin. Because of site limitations and human impacts, wild pistachio trees rarely regenerate. Seedlings are sensitive to excessive cold and longtime drought (Bagheri et al.,2014). In dry periods, the texture and depth of the soil become important enough to determine the survival of new plants (Nejabat et al., 2017).

Competition is one of the most important predictors of seedling growth (Radtke et al., 2003; Sharma et al., 2010), especially in dry forests. Collet and Moguedec (2007) state that local competition affects seedlings mortality. However, in some studies, it is stated that competition is less important in stands with a highgrowing stock and undisturbed population dynamics (Fichtner et al., 2015). Competitors usually affect valuable seedlings by consuming water, nutrients and light. To quantify this competition, numerous indices have been developed. There are mainly two groups of indices described in the literature including i) distanceindependent indices that need the number and specifications of reference and neighbor trees and ii) distance-dependent indices that need more variables like the distance and azimuth of neighbors from reference trees (Contreras et al., 2011).

Revista Árvore. 2018;42(6):e420607
As a background, a comparison of competition indices was conducted by Brodie and Debell (2004) to predict seedling growth of Populus trichocarpa, $P$. deltoides and P. trichocarpa clones in Washington. The results showed that the area delineated by the endpoints of lines around the reference trees was the highest performing index for prediction of both height and DBH growth. Contreras et al., (2011) evaluated 16 indices to predict the basal area increment of Pseudotsuga menziesii, Pinus ponderosa, Larix occidentalis and Pinus contorta in western Montana. They concluded that distance-dependent indices were more correlated with growth than distance-independent ones. Elliott and Vose (1995) indicated that distanceindependent indices were not as well correlated with Pinus strobus L. seedling growth as were distancedependent indices. Kawaletz et al., (2014) used Lorimer's competition index in Germany to define the effect of exotic trees on Quercus robur L. and Carpinus betulus L. as native trees. They concluded that root competition is the most limiting factor that affects the presence of native tree seedlings in natural environments. Collet and Chenost (2006) stated that the sum of the collar diameters of the competitor seedlings in the plot was the best predictor of the diameter and height growth of Fagus sylvatica L. in northeastern France.

The purpose of the present study was to investigate the effects of competition on annual growth and to identify appropriate indices for quantifying a competitive environment for wild pistachio seedlings. For this purpose, we developed linear models to predict any increment in diameter, height, basal area and crown area of seedlings. Moreover, we identified the main competitor species and described their frequency and distribution. As wild pistachio trees rarely regenerate successfully in natural forests, the results of this study may be important to manage the development of young trees and to ensure the survival of adequate pistachio seedlings for the future of forests.

\section{MATERIALAND METHODS}

\subsection{Site description}

This research was carried out in Bagh-Shadi forest managed by the Iranian Institute of Environmental

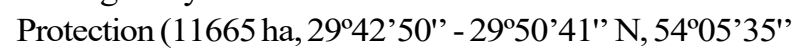
- 54'14'35' $\mathrm{E}, 1,840-2,664 \mathrm{~m})$. The forest is located in the south of Yazd province $(240 \mathrm{~km}$ to the south of Yazd city) and belongs to Iran-Touran biogeoclimatic

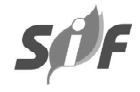


zone. The main forest species are Pistacia atlantica Desf., Acermonspessulanum subsp. cinerascens Boiss., Amygdalus scoparia Spach. and Amygdalus eleagnifolia Spach. The slope is gentle in most areas, with a mean inclination of about $20 \%$. The forest has a semi-arid climate with a mean annual temperature of $17.4 \mathrm{C}^{\circ}$ and precipitation of about $285 \mathrm{~mm}$ (Afroonde et al., 2018). A representative site was chosen in the middle of the forest where regeneration of wild pistachio trees took place in 2002.

\subsection{Methodology}

In the summer of 2017 , fifty sample points were selected in the study area. The sample points were located systematically on a grid of $500 \mathrm{~m}$. The nearest wild pistachio seedling to each point was selected as a reference plant. The measurements were done include the diameter at the root collar (DRC) with a caliper, the total height with a graded rod and the crown diameter with a measuring tape. The measured values were recorded for all the seedlings. Neighborhood information for each reference seedling was collected within a radius five times as large as the radius of the seedling crown. In fact, the search radius was proportional to the size of the reference seedling. A circular plot of $12.56 \mathrm{~m}^{2}$ was established at each sample point to derive the distance-independent indices. At each sample point, all the neighbors were identified. Also, the DRC and the crown diameter of all the neighbors as well as the distance and the azimuth to the reference seedling were measured. Figure 1 shows a competition plot for a reference seedling in the center.

As wild pistachios rarely regenerate in the study area, the only regeneration selected for this study was the one that occurred in 2002 as a great mast year. Hence, all the juvenile pistachios were 15 years old. We identified the most important competitors for wild pistachio seedlings and evaluated their frequency and crown cove.

We quantified the competitive environment that our seedlings confronted with using 11 competition indices illustrated in Table 1. There were three distancedependent indices and eight distance-independent indices.

To evaluate the competition indices, first, the Spearman correlation analysis was conducted with all the 11 competition indices. The growth characteristics included diameter at root collar (DRC), height and basal

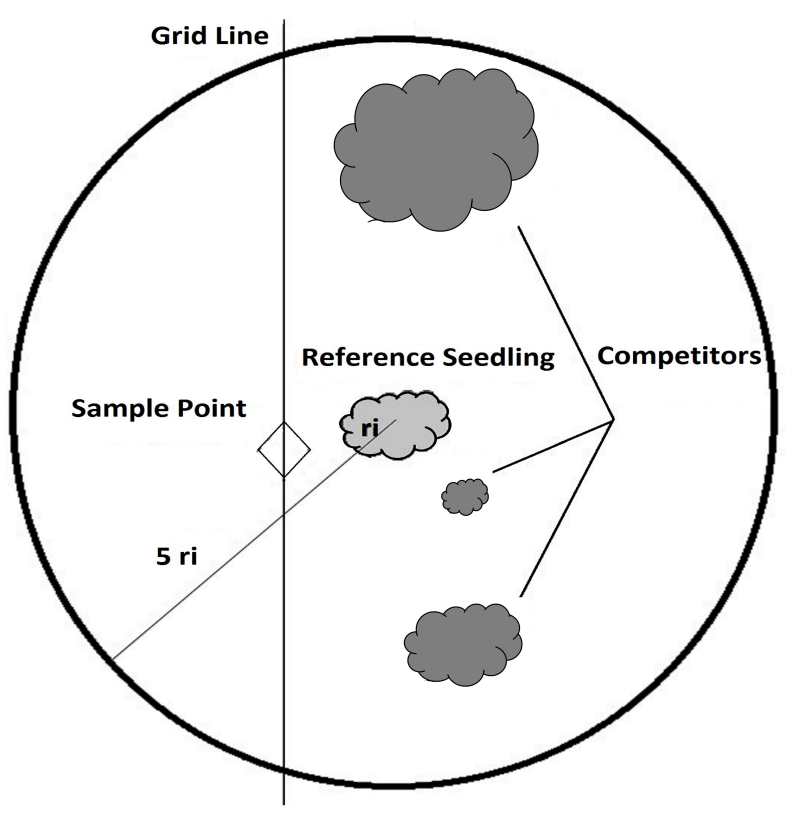

Figure 1 - A competition plot around a reference seedling of Pistacia atlantica in mountain forests of Iran where $r_{i}$ is the crown radius of the reference seedling. The plot radius was five times larger than $r_{i}$. The sample points were selected systematically on a grid, and, at each point, the nearest pistachio seedling was selected for measurement. All the competitors inside the circular plot (marked using solid lines) were measured.

Figura 1 - Esquema representativo de um ponto amostral de competição em torno de uma muda de referência. Onde ri é o raio da copa da plântula de referência. Oraio da parcela era cinco vezes ori. Pontos amostrais foram selecionados sistematicamente em uma grade e em cada ponto, a mudas de pistache mais próxima foi selecionada para medição. Todos os competidores dentro da trama foram medidos.

area increment and crown area development. Then, the linear models for growth variables were fit to evaluate the predictive ability of the log-transformed competition indices. Also, a multiple regression analysis was conducted to quantify the effect of the competition indices in combination with one another. We chose a stepwise method for model selection purposes. The collinearity of predictor variables (using VIF values), the independence of residual values (using the DurbinWatson test) and the normality of residual values (using the Shapiro-Wilks test (Afroonde et al., 2018) were controlled. The models were compared using the adjusted coefficient of determination $\left(R^{2}{ }_{a d j}\right)$ and the normalized root mean squared error (NRMSE).

Revista Árvore. 2018;42(6):e420607 
Table 1-Competition indices evaluated in this study (DI: distance-independent; DD: distance dependent).

Tabela 1-Índices de competição avaliados neste estudo (DI: independente da distância; DD: dependente da distância).

\begin{tabular}{|c|c|c|}
\hline Index & Source & Equation \\
\hline $\mathrm{C}_{1}$ & Reineke (1933) DI & $10^{(\log N+1.605 \times \log d g-1.605)}$ \\
\hline $\mathrm{C}_{2}$ & Rivas et al., (2005) DI & $\sum_{i=1}^{n}(\pi \times$ \\
\hline $\mathrm{C}_{3}$ & Wykoff et al., (1982) DI & $(\pi \times$ \\
\hline $\mathrm{C}_{4}$ & Contreras et al., (2011) DD & $\mathrm{n}$ (number of neighbors) \\
\hline $\mathrm{C}_{5}$ & Hegyi (1974) DD & $\sum_{i=1}^{n} d_{i} /($ \\
\hline $\mathrm{C}_{6}$ & Rouvinen and Kuuluwainen (1997) DD & $\sum_{i=1}^{n} \arctan$ \\
\hline $\mathrm{C}_{7}$ & Stadt et al., (2007) DI & $(1 / S)(\pi / 4)$ \\
\hline $\mathrm{C}_{8}$ & Stadt et al., (2007) DI & $(1 / S)(1 / d)$ \\
\hline $\mathrm{C}_{9}$ & Stadt et al., (2007) DI & $(1 / S)\left(1 / d^{2}\right)$ \\
\hline $\mathrm{C}_{10}$ & Stadt et al., (2007) DI & $\left(\frac{\pi}{s}\right)$ \\
\hline $\mathrm{C}_{11}$ & Burkhar and Tome (2012) DI & $(10000 / n) \times\left(g_{i} / \bar{g}\right)$ \\
\hline
\end{tabular}

$N$ : trees per ha in the plot; $d g$ : quadratic mean diameter $(\mathrm{cm}) ; n$ : number of the neighbors within the competition plot; $c w_{i}$ : crown width of the $i$ th neighbor plant $(\mathrm{m}) ; S$ : plot size $\left(\mathrm{m}^{2}\right) ; d_{\text {in }}$ : diameter at root collar of the neighbor plants larger than the reference seedling $(\mathrm{m})$; $G$ : total basal area of the trees within the plot $\left(\mathrm{m}^{2} \mathrm{ha}^{-1}\right) ; d:$ diameter at root collar of the $i$ th neighbor plant $(\mathrm{cm}) ; d$ : diameter at root collar of the reference seedling $(\mathrm{cm})$; dist $t_{i}$ : horizontal distance from the $i$ th neighbor plant to the reference seedling $(\mathrm{m})$; $g$ : basal area of reference seedling; $\bar{g}$ : average basal area of neighbor plants

\section{RESULTS}

The results showed that Amygdalus scoparia (47.1\%) and Pistacia atlantica 30.4\%) were the most important competitors, together representing $77.5 \%$ of the competitors. The other competitors included Ephedra maucronata (3.6\%), Amygdalus lycioides (8\%), Acer monspessulanum (6.5\%), Pteropyrum aucheri $(0.07 \%)$ and Prunus sp. (0.07\%). Three percent of the reference seedlings had no competitors. The largest collar diameter and crown area were observed in Acer monspessulanum, but they made up only $6.5 \%$ of the competitors' frequency. Only one tree of Prunus sp. and Pteropyrum aucheri species was observed in the sample plots. It was also observed that most of the competitors lay within a distance of 0.5 to 2 meters from the reference seedling (Figure 2). Some wild pistachio seedlings grow directly inside the crown cover of nurse plants. Hence, they lay so close to the collar of competitors. According to the results, DRC distribution for main competitors follows an exponential form. It indicates that wild pistachio seedlings avoid growing near large plants (Figure 2).

The mean height of the reference seedlings was $153.6 \mathrm{~cm}$, the mean collar diameter was $2.74 \mathrm{~cm}$, the mean basal area was $15.83 \mathrm{~cm}^{2}$, and the mean crown area was $0.58 \mathrm{~m}^{2}$. As all the reference seedlings were

Revista Árvore. 2018;42(6):e420607 

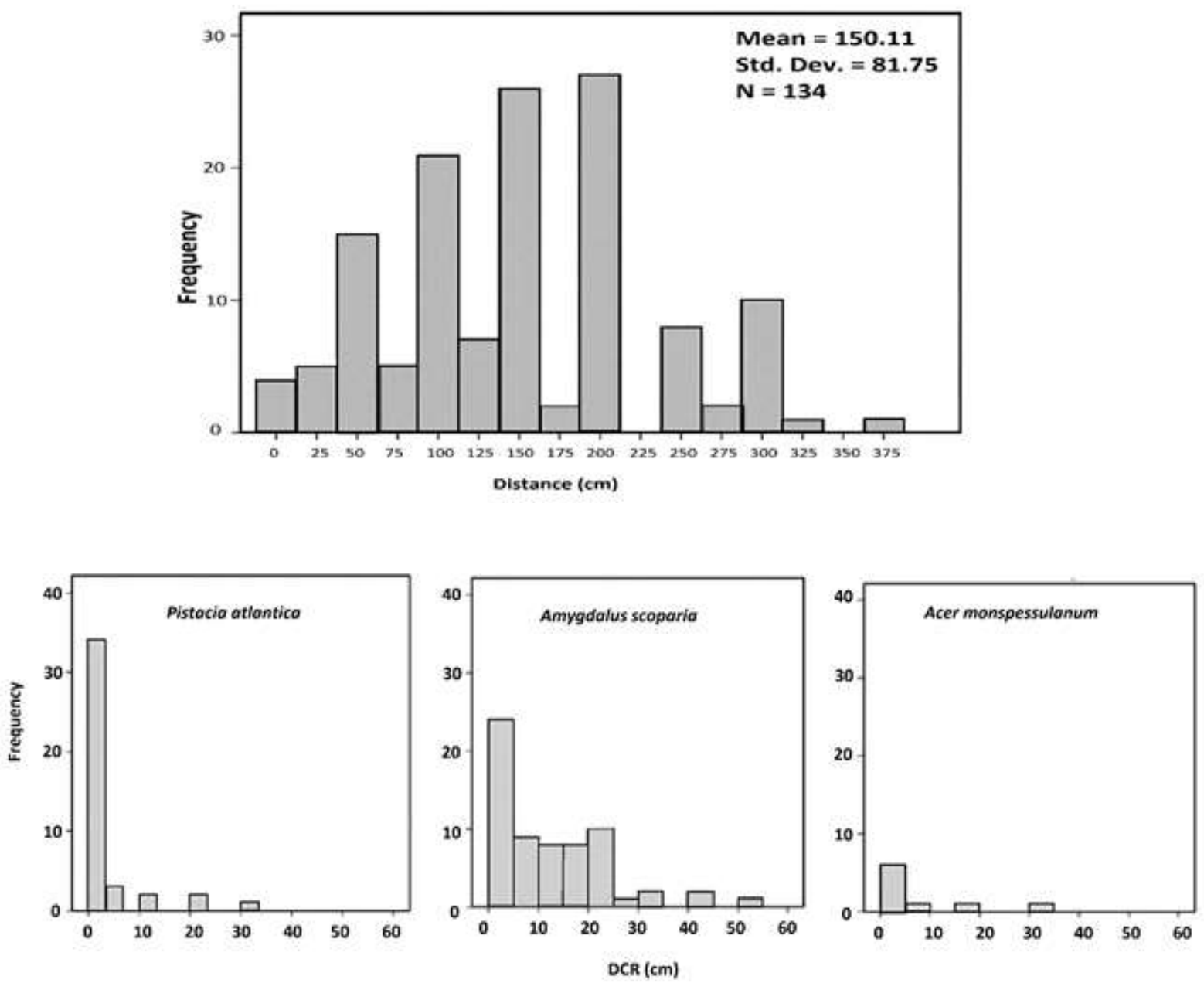

Figure 2 - Frequency of distance between the reference seedlings of Pistacia atlantica and the competitors (upside) and diameter at root collar (DRC) distribution of the competitor trees (downside).

Figura 2 - Frequência de distância entre mudas de referência de Pistacia atlantica e competidores (acima) e diâmetro do coleto (DRC) de espécies competidoras (abaixo).

15 years old, they had individually grown $10.24 \mathrm{~cm}$ in height, $1.8 \mathrm{~mm}$ in collar diameter, $0.04 \mathrm{~m}^{2}$ in crown area, and $0.46 \mathrm{~cm}^{2}$ in basal area on average.

The Spearman correlation matrix is presented in Table 2. Three competition indices including $\mathrm{C}_{3}, \mathrm{C}_{4}$ and $\mathrm{C}_{11}$ had a significant correlation with seedling height growth. There was a negative correlation between $\mathrm{C}_{3}$ and height growth, but a positive correlation was observed for $\mathrm{C}_{4}$. The competition indices including $\mathrm{C}_{5}, \mathrm{C}_{8}$ and $\mathrm{C}_{9}$ had a significant negative correlation with seedling DRC growth. For crown area growth, $\mathrm{C}_{2}, \mathrm{C}_{8}$ and $\mathrm{C}_{10}$ indices were negatively correlated, while $\mathrm{C}_{4}$ and $\mathrm{C}_{6}$ had a positive correlation.
Since weak models were attained in simple linear regression, a log-transformed combination of competition indices as predictors was tested. Surprisingly, the coefficient of determination and the model precision were improved (Table 3). For example, the coefficient of determination was changed from 0.45 to 0.85 , and NRMSE decreased from 16.65 to 8.5 , yielding a more precise model for diameter growth.

It seems that $\mathrm{C}_{4}, \mathrm{C}_{7}$ and $\mathrm{C}_{5}$ indices can generally be used to estimate the growth parameters of wild pistachio seedlings because they are present in almost all models. 
Table 2 - Bivariate correlation between Pistacia atlantica seedling growth and competition indices in mountain forests, Iran.

Tabela 2 - Resultados da correlação bivariada entre crescimento de plântulas de Pistacia atlantica e índices de competição em florestas montanas, Irã.

\begin{tabular}{|c|c|c|c|c|c|c|c|c|c|c|c|c|}
\hline & & $\mathrm{C}_{1}$ & $\mathrm{C}_{2}$ & $\mathrm{C}_{3}$ & $\mathrm{C}_{4}$ & $\mathrm{C}_{5}$ & $\mathrm{C}_{6}$ & $\mathrm{C}_{7}$ & $\mathrm{C}_{8}$ & $\mathrm{C}_{9}$ & $\mathrm{C}_{10}$ & $\mathrm{C}_{11}$ \\
\hline $\begin{array}{l}\text { Height } \\
\text { Increment } \\
\left(\mathrm{cm} \cdot \text { year }^{-1}\right)\end{array}$ & $\begin{array}{c}\mathrm{r} \\
\mathrm{P}- \\
\text { value }\end{array}$ & $\begin{array}{l}-0.03 \\
0.847\end{array}$ & $\begin{array}{l}-0.12 \\
0.404\end{array}$ & $\begin{array}{c}-0.41 \\
0.003\end{array}$ & $\begin{array}{c}0.37 \\
0.009\end{array}$ & $\begin{array}{c}0.03 \\
0.851\end{array}$ & $\begin{array}{c}0.25 \\
0.075\end{array}$ & $\begin{array}{l}-0.04 \\
0.771\end{array}$ & $\begin{array}{l}-0.19 \\
0.181\end{array}$ & $\begin{array}{l}-0.19 \\
0.185\end{array}$ & $\begin{array}{l}-0.12 \\
0.404\end{array}$ & $\begin{array}{r}0.38 \\
0.006\end{array}$ \\
\hline $\begin{array}{l}\text { DRC } \\
\text { Increment } \\
\left(\mathrm{cm} \cdot \text { year }^{-1}\right)\end{array}$ & $\begin{array}{c}\mathrm{r} \\
\mathrm{P}- \\
\text { value }\end{array}$ & $\begin{array}{l}-0.06 \\
0.663\end{array}$ & $\begin{array}{l}-0.24 \\
0.109\end{array}$ & $\begin{array}{l}-0.25 \\
0.097\end{array}$ & $\begin{array}{c}0.17 \\
0.260\end{array}$ & $\begin{array}{l}-0.31 \\
0.035\end{array}$ & $\begin{array}{c}0.10 \\
0.516\end{array}$ & $\begin{array}{l}-0.07 \\
0.624\end{array}$ & $\begin{array}{l}-0.45 \\
0.002\end{array}$ & $\begin{array}{c}-0.35 \\
0.016\end{array}$ & $\begin{array}{l}-0.24 \\
0.109\end{array}$ & $\begin{array}{r}0.27 \\
0.070\end{array}$ \\
\hline $\begin{array}{l}\text { Crown } \\
\text { Area } \\
\text { Growth } \\
\left(\mathrm{m}^{2} . \text { year }^{-1}\right)\end{array}$ & $\begin{array}{c}\mathrm{r} \\
\mathrm{P}- \\
\text { value }\end{array}$ & $\begin{array}{l}-0.19 \\
0.189\end{array}$ & $\begin{array}{l}-0.34 \\
0.016\end{array}$ & $\begin{array}{l}-0.22 \\
0.134\end{array}$ & $\begin{array}{c}0.42 \\
0.003\end{array}$ & $\begin{array}{l}-0.05 \\
0.736\end{array}$ & $\begin{array}{c}0.35 \\
0.012\end{array}$ & $\begin{array}{l}-0.17 \\
0.232\end{array}$ & $\begin{array}{r}-0.42 \\
0.003\end{array}$ & $\begin{array}{l}-0.25 \\
0.081\end{array}$ & $\begin{array}{l}-0.34 \\
0.016\end{array}$ & $\begin{array}{r}0.23 \\
0.103\end{array}$ \\
\hline
\end{tabular}

\section{DISCUSSION}

The results of our study showed that Amygdalus scoparia is the most important competitor, implying that wild pistachio seedlings usually prefer it as a nurse. In some studies, Amygdalus scoparia has been considered as an important factor in pistachio seedlings survival (Bagheri et al., 2014). Also seedlings rarely grow in open spaces because they need to be protected by a nurse tree in early life. Acer monspessulanum trees made up only $6.5 \%$ of the competitors' frequency. It is because wild pistachios grow frequently near or inside the crown cover of shrubs rather than large trees.
The results of the present study indicated that most of the competitors lay within a distance of 0.5 to 2 meters from the reference seedling. Also, some wild pistachio seedlings had grown directly inside the crown cover of the nurse trees. Although the competition affected all the seedlings unequally, the individual seedlings had grown annually $10 \mathrm{~cm}$ in height, $2 \mathrm{~mm}$ in collar diameter, $0.04 \mathrm{~m}^{2}$ in crown area, and $0.46 \mathrm{~cm}^{2}$ in basal area on average. In another study, the annual growth of height and diameter for pistachio seedlings was 10 and 1.9 centimeters respectively. Also, the crown area growth was $1.3 \mathrm{~cm}$ per year (Mohammadi et al.,

Table 3 - Model coefficients and fit statistics for log-linear models.

Tabela 3 - Coeficientes do modelo e estatísticas de ajuste para modelos log-lineares.

\begin{tabular}{|c|c|c|c|c|c|c|c|c|}
\hline Dependent & Predictor & Parameter estimate & $\mathrm{t}$ & p-value & $\mathrm{R}^{2}$ & $\mathrm{R}_{\text {adj }}^{2}$ & RMSE & $\begin{array}{c}\text { NRMSE } \\
\%\end{array}$ \\
\hline \multirow{3}{*}{$\begin{array}{l}\text { DRC growth } \\
\left(\mathrm{cm} . \text { year }^{-1}\right)\end{array}$} & Constant & 0.105 & 14.1 & 0.000 & & & & \\
\hline & $\log C_{7}$ & 0.178 & 14.98 & 0.000 & & & & \\
\hline & $\begin{array}{l}\log C_{5} \\
\log C_{4}\end{array}$ & $\begin{array}{l}-0.195 \\
-0.53\end{array}$ & $\begin{array}{l}-16.92 \\
-4.51\end{array}$ & $\begin{array}{l}0.000 \\
0.000\end{array}$ & 0.86 & 0.85 & 0.029 & 8.5 \\
\hline \multirow{2}{*}{$\begin{array}{l}\text { Height growth } \\
\left(\mathrm{cm} . \text { year }^{-1}\right)\end{array}$} & (Constant) & 6.22 & 15.56 & .000 & & & & \\
\hline & $\begin{array}{l}\log C_{5} \\
\log C_{7}\end{array}$ & $\begin{array}{c}-4.97 \\
4.1 \\
\end{array}$ & $\begin{array}{c}-6.47 \\
5.53 \\
\end{array}$ & $\begin{array}{l}.000 \\
.000 \\
\end{array}$ & 0.48 & 0.46 & 0.97 & 7.9 \\
\hline \multirow{4}{*}{$\begin{array}{l}\text { Basal area } \\
\text { growth } \\
\left(\mathrm{cm}^{2} . \text { year }^{-1}\right)\end{array}$} & (Constant) & 0.08 & 1.69 & 0.097 & & & & \\
\hline & $\log \mathrm{C}_{7}$ & 0.86 & 11.45 & .000 & 0.77 & 0.76 & 0.19 & 10.2 \\
\hline & $\log \mathrm{C}_{5}$ & -0.9 & -12.33 & .000 & & & & \\
\hline & $\log C_{4}$ & -0.26 & -3.55 & .001 & & & & \\
\hline \multirow{7}{*}{$\begin{array}{l}\text { Crown area } \\
\text { growth } \\
\left(\mathrm{m}^{2} \text { year }^{-1}\right)\end{array}$} & (Constant) & 0.33 & 5.26 & .000 & & & & \\
\hline & $\log C_{8}$ & -0.076 & -6.94 & .000 & & & & \\
\hline & $\log C_{4}^{8}$ & 0.17 & 7.06 & .000 & & & & \\
\hline & $\log C_{11}^{4}$ & -0.044 & -7.8 & .000 & 0.75 & 0.72 & 0.018 & 8.1 \\
\hline & $\log C_{1}$ & -0.087 & -4.5 & .000 & & & & \\
\hline & $\log C_{7}$ & 0.058 & 4.22 & .000 & & & & \\
\hline & $\log C_{6}$ & -0.021 & -2.12 & .040 & & & & \\
\hline
\end{tabular}

Revista Árvore. 2018;42(6):e420607 
2013). The results showed that DRC distribution for the main competitors would follow an exponential form. It indicates that reference seedlings avoid growing near large plants.

Competition enhances the height growth and diminishes the crown and diameter growth of wild pistachio seedlings. In fact, seedlings at a higher level of competition exhibit lower diameter growth but higher height growth. Although wild pistachios are the climax trees in the central forests of Iran, their seedlings highly depend on nurse trees. They grow inside the crown cover of the shrubs that accompany them, such as Ephedra maucronata, Amygdalus spp. and Pteropyrum aucheri. The more the competition pressure, the better the height growth. This nursing protects seedlings from grazing and intensive radiation of sunlight. On the other hand, it restricts their diameter growth. Since wild pistachios are a slow-growing species, they gradually grow to higher elevations and finally defeat the nurse plants.

We did not measure the amount of light available to the seedlings, nor was it possible to calculate light values. This was because of the low stock of trees in the study area that makes light available enough for all the trees. In addition, some wild pistachio seedlings grow directly inside the crown cover of nurse trees and are not visible until they are about one meter high. In this regard, some studies such as Contreras et al., (2011) reported that the association between growth and light values was weak and that the corresponding indices could not capture the variation of light availability in the forests of Montana.

The diameter at the root collar of reference seedlings was found to be a useful variable in many studies (White and Elliott, 1992). It was also strongly correlated with the seedling quality (Binotto et al., 2010). Logtransformation did not change the predictive ability of competition indices for height growth as the target variable. In a study, White and Elliott (1992) found that seedling height in red pines did not respond to competition because of the short period of the study. In our study, however, a 15-year period after germination was long enough to affect the height growth of the seedlings. More precise and robust models have been achieved for predicting basal area and crown area growth based on log-transformed indices (i.e. independent variables). Unlike some studies, such as Contreras et al. (2011), we were not able to achieve better models by the log-transforming of growth parameters (i.e. dependent variables).
It seems that $\mathrm{C}_{7}, \mathrm{C}_{4}$ and $\mathrm{C}_{5}$ indices can generally be used to estimate the growth parameters of wild pistachio seedlings because they are present in almost all models. In some studies such as Collet and Chenost (2006), it was indicated that local density had a strong negative influence on the diameter growth of European beech seedlings in northern France. Similarly, in the current study, $\mathrm{C}_{4}$ index was found suitable for predicting diameter, basal area and crown area growth. Amiri and Naghdi (2016) stated that distance-dependent indices were more suitable for predicting the growth parameters of oriental beech in northern Iran. They recommended additional predictors such as diameter and height to be included in competition indices. However, we found that distance-independent indices were superior in evaluating the competitive environment of wild pistachios with higher parsimony. Hegyi competition index $\left(\mathrm{C}_{5}\right)$ could explain $46 \%$ and $41 \%$ of variations in the height and crown width of Persian oak trees respectively (Hosseini et al., 2013). In our study, Hegyi index was able to explain only $9 \%$ of variations in DRC growth, and it was not present in compound models. Competitor basal area was as effective as the crowding index to predict the growth in the mature boreal mixed forests of Alberta (Stadt et al., 2007). Here, $C_{11}$ index, which is calculated based on the basal area of competitor trees, was one of the best predictors of height growth; however, in compound models, it was suitable only for predicting the crown area development.

In this study, we evaluated the predictive ability of distance-dependent and distance-independent competition indices and their relationship to the growth characteristics measured in 2017. As all the seedlings were 15 years old, we were able to account for their annual growth of diameter, height, basal area and crown area. As also seen by other researchers such as Contreras et al., (2011), there is a need for tree growth modeling in the case of forest trees using permanent plots. Unfortunately, permanent plot procedures are not common even in the commercial forests of northern Iran. In that protected area, it is recommended to establish a permanent plot network. To do so, our sample points can be used to follow the future growth of valuable wild pistachio trees.

The spatial pattern of neighbor plants has not been recorded in the current study because the level of competition is more important than the competitor distribution pattern (MacDonald et al., 1990). Moreover, 
most competition indices are independent of competitors' distribution (Contreras et al., 2011). We have been interested in modeling annual seedling growth rather than the growth of mature trees. This is because wild mature pistachio trees mainly have little problem competing with other tree species, whereas their seedlings must survive in a harsh competitive environment. Due to the structural difference of forest stands and dissimilarity of growth conditions available to wild pistachio seedlings, the models developed in this study are suited only to the central forests of Iran not to the western mountains. It is not clear how wild pistachio seedlings will respond to releasing from competitors' pressure. So, a field study, as recommended by some researchers like van Kuijk et al., (2014), is necessary to evaluate and model the seedling growth under various release treatments. As competition thresholds may be different for the survival and growth of wild pistachio seedlings, supplementary research is encouraged to define the minimum and maximum abundance of competitors.

\section{CONCLUSION}

In this study, we evaluated three distancedependent and eight distance-independent competition indices to predict the growth of wild pistachio seedlings in the central forests of Iran. We found that some competition indices have a moderate correlation with seedling growth, indicating that there is a noticeable competition. The seedlings were mainly in competition with Amygdalus scoparia followed by other wild pistachio seedlings. The height growth of the seedlings was improved as the number of the competitors increased. The diameter and the basal area of the seedlings decreased as the sum diameter of the neighbors increased. The crown area of the reference seedlings decreased as the total crown area of the neighbors increased. Our results showed that some distance-independent indices can provide a good description of competitive environment for wild pistachio seedlings. The advantage of these indices is that they do not need neighboring tree locations.

As the best predictors in compound models use 'diameter at root collar' both for reference and competitor trees, this variable can be recommended to quantify the competitive environment for wild pistachio seedlings across the central forests of Iran. Stand density was also a suitable predictor of seedling growth in compound models. The models calibrated in this study will be a useful tool to assess the effects of protection strategies in the management of Iranian central forests. These models actually make it possible to check how valuable pistachio seedlings compete in protected areas in comparison with unprotected ones, and whether conservation has been able to provide better conditions for pistachio seedlings.

\section{REFERENCES}

Afroonde A, Kiani B, Attarod P. Allometric equations for determining volume and biomass of Acer monspessulanum L. subsp. cinerascens multi-stemmed trees. Caspian Journal of Environmental Science. 2018;16(2):111-9.

Amiri M, Naghdi R. Assessment of competition indices of an unlogged oriental beech mixed stand in Hyrcanian forests, Northern Iran. Biodiversitas. 2016;17(1):306-14.

Bagheri J, Salehi A, Taheri K. Effective factors on regeneration establishment and quantitative and qualitative characteristics of Pistacia atlantica in different physiographic conditions (case study: Khojir National Park). Ecology of Iranian Forest. 2014;2(3):1-12.

Binotto AF, Lucio A, Lopes SJ. Correlation between growth variables and the Dickson quality index in forest seedlings. Cerne. 2010;16(4):457-64.

Brodie LCH, Debell DS. Evaluation of field performance of poplar clones using selected competition indices. New Forest. 2004;27:201-14.

Burkhart HE, Tome M. Modeling forest trees and stands. Dordrecht: Springer; 2012.

Collet C, Chenost C. Using competition and light estimates to predict diameter and height growth of naturally regenerated beech seedlings growing under changing canopy conditions. Forestry. 2006;79(5):489-502.

Collet C, Moguedec GL. Individual seedling mortality as a function of size, growth and competition in naturally regenerated beech seedlings. Forestry. 2007;80(4):359-70.

Contreras MA, Affleck D, Chung W. Evaluating tree competition indices as predictors of basal area increment in western Montana forests. Forest Ecology and Management. 2011;262:1939-49.

Revista Árvore. 2018;42(6):e420607 
Elliott JK, Vose JM. Evaluation of the competitive environment for white pine (Pinus strobus L.) seedlings planted on prescribed burn sites in the southern Appalachians. Forest Science. 1995;41(3):513-30.

Fichtner A, Forrester DI, Hardtle W, Sturm K, von Oheimb G. Facilitative-competitive interactions in an old-growth forest: the importance of large-diameter trees as benefactors and stimulators for forest community assembly. PLoS ONE. 2015;10(3):e0120335.

Hegyi F. A simulation model for managing jack pine stands. In: Fries J, editor. Proceedings of IUFRO meeting S4.01.04 on Growth models for tree and stand simulation. Stockolm: Royal College of Forestry; 1974. p.74-90.

Hosseini A, Hosseini SM, Rahmani A, Azadfar D. The role of competition in drought related tree dieback in Persian oak (Quercus brantii) forests, central Zagros, Iran. International Journal of Environmental Sciences. 2013;3(6):2208-16.

Kawaletz H, Mölder I, Annighöfer P, Terwei A, Zerbe $\mathrm{S}$, Ammer CH. Back to the roots: how do seedlings of native tree species react to the competition by exotic species? Annals of Forest Science. 2014;71(3):337-47.

MacDonald B, Morris DM, Marshal PL. Assessing components of competition indices for young boreal plantations. Canadian Journal of Forest Research. 1990;20(7):1060-68.

Mohammadi F, Jalilvand H, Poormajidian MR, Rezaeian S. Investigating the success of broad leave plantations in Rimeleh, Loristan Province, Iran. In: Proceedings of National Conference on Passive Defense in Agriculture. Gheshm: 2013. p.6403-14.

Nejabat M, Negahdarsaber M, Ghahari GH. Range of soil and climate characteristics appropriate for Pistacia atlantica forest development and rehabilitation (case study: Fars province, Iran). Journal of Water and Land Development. 2017;32:71-8.

Pourreza M, Shaw JD, Zangeneh H. Sustainability of wild pistachio (Pistacia atlantica Desf.) in Zagros forests, Iran. Forest Ecology and Management. 2008;255:3667-71.

Quattrocchi U. CRC world dictionary of medicinal and poisonous plants: common names, scientific names, eponyms, synonyms, and etymology. Boca Raton: Taylor and Francis; 2012.

Radtke PJ, Westfall JA, Burkhart HE. Conditioning a distance-dependent competition index to indicate the onset of inter-tree competition. Forest Ecology and Management. 2003;175:17-30.

Reineke LH. Perfecting a stand density index for evenaged forest. Journal of Agricultural Researches. 1933;46(7):627-38.

Rivas JJC, Gonzalez JG, Aguirre O, Hernandez FG. The effect of competition of individual tree basal area growth in mature stands of Pinus cooperi Blanco in Durango (Mexico). European Journal of Forest Research. 2005;124:133-42.

Rouvinen S, Kuuluvainen T. Structure and asymmetry of tree crowns in relation to local competition in a natural mature Scot pine forest. Canadian Journal Forest Research. 1997;27:890-902.

Sharma M, Bell FW, White RG, Morneault A, Towill WD. Seedling size and woody competition most important predictors of growth following free-to-grow assessments in four boreal forest plantations. The Forest Chronicle. 2010;86(2):213-24.

Stadt KJ, Huston C, Coated KD, Feng Z, Dale MRT, Lieffers VJ. Evaluation of competition and light estimation indices for predicting diameter growth in mature boreal mixed forests. Annals of Forest Science. 2007;64(5):477-90.

van Kuijk M, Anten NPR, Oomen RJ, Schieving F. Stimulating seedling growth in early stages of secondary forest succession: a modeling approach to guide tree liberation. Frontiers of Plant Science. 2014;5:1-13.

Wykoff WR, Crookston NL, Stage AR. User's guide to the stand prognosis model. Washington: USDA Forest Service; 1982. 119p. (General Technical Report, INT-133)

White AS, Elliott KJ. Predicting the effects of hardwood competition on red pine seedling growth Canadian Journal of Forest Research. 1992;22(10):1510-15. 